\title{
Measles outbreak in Andalusia, Spain, January to August 2011
}

J M Mayoral Cortés (josem.mayoral.sspa@juntadeandalucia.es) ${ }^{1}$, E Pérez Morilla ${ }^{1}$, V Gallardo García1 ${ }^{1}$ J M Navarro Marí²,

M Pérez Ruiz ${ }^{2}$, R Hermosilla ${ }^{3}$, J Díaz-Borrego ${ }^{3}$, E Rodríguez Romero' ${ }^{1}$, Ruiz Fernandez ${ }^{1}$

1. Regional Ministry of Health of the Government of Andalusia, Seville, Spain

2. Andalusian Health Service, Granada, Spain

3. Andalusian Health Service, Seville, Spain

Citation style for this article:

Mayoral Cortés JM, Pérez Morilla E, Gallardo García V, Navarro Marí JM, Pérez Ruiz M, Hermosilla R, Díaz-Borrego J, Rodríguez Romero E, Ruiz Fernandez J. Measles outbreak in Andalusia, Spain, January to August 2011. Euro Surveill. 2012;17(42): pii=20300. Available online: http://www.eurosurveillance.org/ViewArticle.

aspx?Articleld $=20300$

Article submitted on 23 January 2012 / published on 18 October 2012

On 7 January 2011, a six year-old child living in a Roma community near Seville, southern Spain, was hospitalised with measles. Contact tracing identified a probable index case with onset of symptoms on 20 December 2011 and several unreported cases among children under the age of 15 years in the same town. The outbreak initially spread in districts in the city of Seville with a high proportion of Roma residents, and later to other cities and towns in Andalusia. While some towns experienced wide spread of the disease with significant clusters of cases, most of the affected locations saw non-clustered cases or very few secondary cases. The outbreak resulted in 1,759 confirmed or probable cases of which $393(19 \%)$ required hospitalisation. Measles virus of genotype D4 was diagnosed in more than half of the cases. Significant differences ( $p<0.0001$ ) by age group were found between clustered and non-clustered cases. The highest proportion of clustered cases occurred in the age group of 5-14 yearolds, while the highest proportion of non-clustered cases was seen in those older than 29 years. The last confirmed case related to this outbreak was reported on 20 August 2011.

\section{Introduction}

Measles is a highly infectious viral disease capable of causing large outbreaks. Because humans are the only reservoir of measles virus and there is an effective vaccine which induces lasting immunity in $98-99 \%$ of vaccinated children, it is theoretically possible to eradicate the disease. The countries in the European region of the World Health Organization (WHO) have committed to eliminating measles by 2015 . Previous elimination targets in 2007 and 2010 were not met and the resurgence of measles in 2010 and 2011 put the 2015 target at stake $[1,2]$.

The measles elimination plans for Spain and for Andalusia were launched in $2001[3,4]$ in response to the 2015 WHO target for stopping indigenous measles transmission. The two strategic goals of the Andalusian plan were to improve the surveillance system for early case detection and control of the transmission and to increase vaccination coverage in children in order to improve population immunity.

A monovalent vaccine against measles had been in use in Spain since 1978, when the measles-mumps-rubella (MMR) vaccine was introduced in 1981 for children aged 15 months. In 1995, a second dose for children aged 11 years was included in the calendar. The age of administration of the second dose was changed to six years in 1999 and later to three years in 2004 [5].

The last major outbreak in Andalusia happened in 1986 , with an incidence rate of 1,007 cases of measles per 100,000 population. Thereafter, the annual rate decreased to 39 cases per 100,000 population in 1995, the last epidemic year. The rate decreased further to 14 per 100,000 in 1996, and from 1997 to 2008 , incidence rates were very low ( $\$ 1$ case per 100,000), except for two isolated outbreaks in 2003 in Almeria ( 2.51 cases per 100,000 population) and Algeciras in 2008 (3.0 cases per 100,000 population) [6]. Both outbreaks affected mostly unvaccinated young adults, but also spread to unvaccinated children under 15 months of age. Between 2002 and 2007, the number of cases reported annually ranged from o to 4 .

In 2010 this trend was broken by the appearance of a more widespread outbreak of measles that began in the city of Granada [7] in a group of adolescents who were not vaccinated on ideological grounds. It lasted for 10 months and spread to various municipalities in the eastern provinces of Andalusia. It was followed by the outbreak described in this paper, which reached a large number of municipalities in Andalusia in 2011. Both the 2010 and 2011 outbreaks were notified in the context of a widespread epidemic wave that has been affecting different European countries since 2008 $[8,15]$.

\section{Methods}

The case definition in this outbreak investigation follows essentially the clinical, laboratory and epidemiological criteria established by the Europe the Centre 


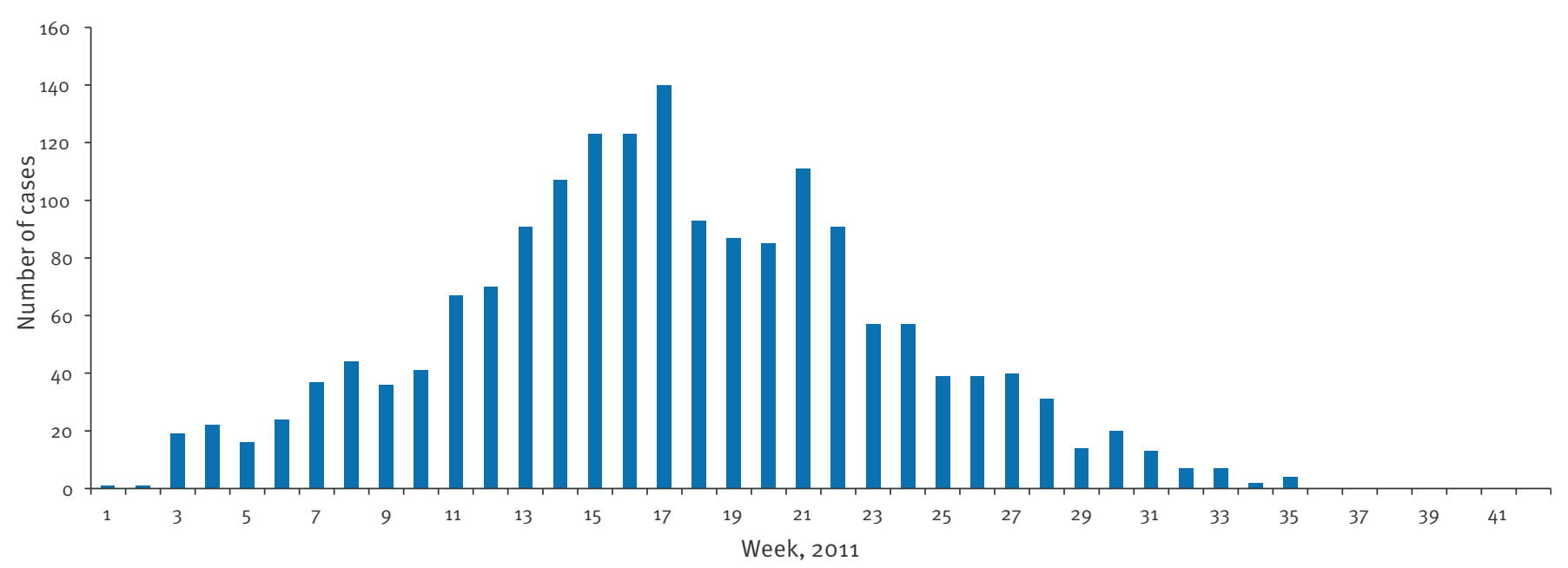

for Disease Prevention and Control (ECDC) $[16,17]$. Confirmed cases were defined on the basis of clinical and laboratory criteria, while probable cases of measles were defined on the grounds of clinical criteria and an epidemiological link to a confirmed case between 7 and 18 days before onset of symptoms.

Laboratory diagnosis was achieved by demonstration of specific IgM antibodies, and/or virus detection by real-time RT-PCR targeting a fragment of the conserved $\mathrm{F}$ gene, and/or viral culture in a B95a cell line. The measles genotype was determined in positive samples or viral isolates by PCR and subsequent sequencing of the 450 nucleotides encoding the $\mathrm{C}$-terminus of the nucleoprotein, as recommended by the WHO. Laboratory diagnosis was carried out at the regional virus reference laboratory of the Andalusian epidemiological surveillance system (Sistema de Vigilancia Epidemiológica de Andalucía, SVEA) at the University Hospital Virgen de las Nieves in Granada. Genetic characterisation in patient samples and viral isolates was performed at the national reference laboratories, the National Centre of Microbiology at Instituto de Salud Carlos III in Madrid and the Hospital Ramón y Cajal in Madrid.

The reporting of notifiable diseases, including measles, to the SVEA is done in an automated manner. Cases are recorded in digital health records ('Diraya') by physicians in all primary health centres in Andalusia. The clinical and epidemiological information recorded in Diraya is sent daily to the SVEA computer application, where epidemiological and laboratory information of every reported case is completed when available.

We compared characteristics of cases in municipalities having non-clustered cases or incidence rates below 100 cases per 100,000 population, with those occurred in municipalities with major clusters or higher incidence rates. In the city of Seville (703,021 inhabitants) we distinguished similarly between districts with more than 100 cases per 100,000 and those with fewer.

\section{Outbreak description}

The first measles case in this outbreak was reported on 7 January 2011 in a six year-old Roma child with no history of vaccination. After admission to hospital, the diagnosis was confirmed by PCR. Contact tracing identified a likely primary case with onset of symptoms on 20 December 2010, along with other unvaccinated cases who attended the same school. All these cases were resident in the same district, placed in a municipality of 21,025 inhabitants near Seville. Vaccination coverage with two doses of measles-containing vaccine among school and preschool children between 3 and 11 years of age enrolled at this school was $56.0 \%$.

After the end of this outbreak in week 35 of 2011, 1,759 confirmed or probable cases (Figure 1) had been reported in Andalusia. The same measles virus genotype D4 was identified in more than $50 \%$ of cases. The overall incidence rate was 21 cases per 100,000. Cases related to this outbreak occurred in at least 120 municipalities of Andalusia, representing $16 \%$ of all Andalusian municipalities. Most of the cases were non-clustered or clustered with incidence rates below 100 cases per 100,000 population, although $88.1 \%$ occurred in towns in the province of Seville. A total of 827 cases ( $47 \%$ ) occurred in 14 clusters, with incidence rates of over 100 cases per 100.000 , in five districts of the city of Seville and nine in nearby municipalities, including the one where the outbreak began and in which incidence rates reached 489.9 cases per 100,000 . In the city of Seville, which registered $39.9 \%$ of the reported cases, the incidence rate was 99.8 per 100,000 .

The age of cases ranged from two weeks to 57 years with a mean of 16.5 years (median: 16 years). The mean 
FIGURE 2

Measles, percentage of cases by age group, Andalusia, January to August $2011(\mathrm{n}=1,759)$

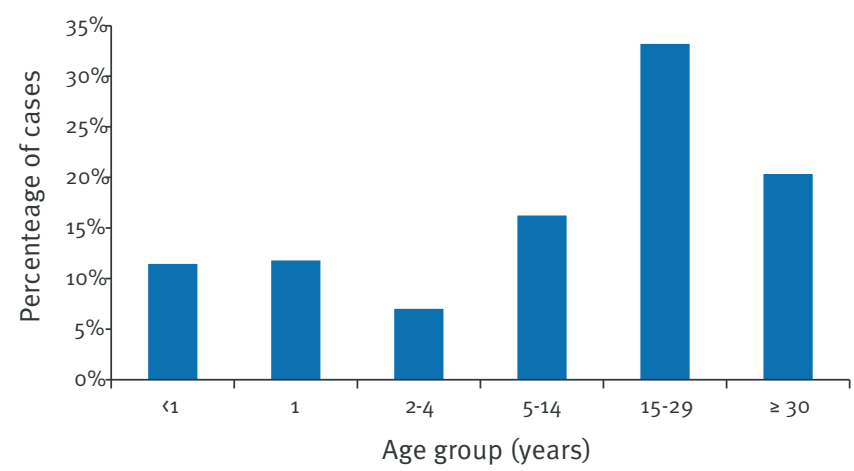

age of cases increased over time and was 15 years during the first four weeks and 19 years during the final four weeks of the outbreak.

Of all cases, $23.2 \%$ were younger than two years, $23,2 \%$ were $2-14$ years-old, $33.2 \%$ were $15-29$ years-old and $20.3 \%$ were 29 years and older (Figure 2). Some $16,2 \%$ occurred in children younger than 15 months of age, who were not eligible for vaccination. However, the highest incidence rates were seen in those younger than two years: 266.4 cases per 100,000 in children younger than one year and 242.5 cases per 100,000 in one year-old children (Figure 3 ).

A significant difference ( $p<0.0001$ ) was found between the mean age of clustered cases (14.4 years) and nonclustered cases (18.6 years), due to significant differences in the proportions of cases by age group, We found no significant differences in the incidence rate in children younger than 15 months (not vaccinated due to their age) when comparing the major clusters of this outbreak (rates over 100 cases per 100,000) with non-clustered cases or clusters with low incidence rate (Table). However, in major clusters, $23.2 \%$ of the cases

\section{FIGURE 3}

Measles incidence rate by age group, Andalusia, January to August $2011(n=1,759)$

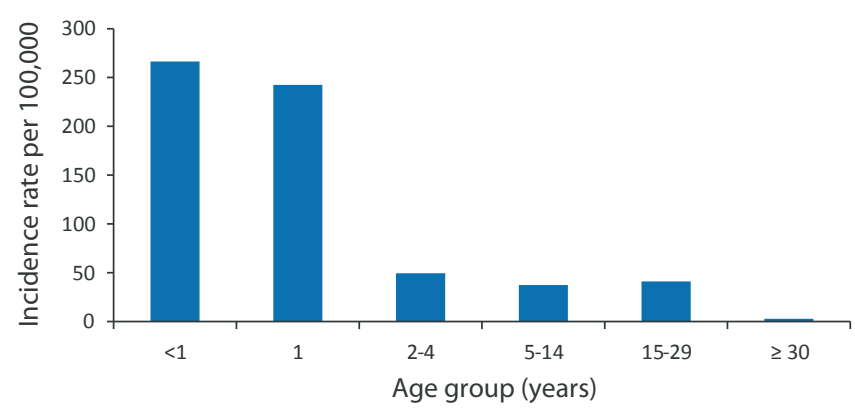

occurred in the age group of 5-14 year-olds, compared with only $12.2 \%$ in non-clustered cases or clusters with low rate of incidence ( $p<0.0001)$. These percentages were reversed in older age-groups, with $11.7 \%$ and $27.6 \%$, respectively, in cases older than 29 years (p<0.0001).

Among the 535 cases with information about history of vaccination, $68.2 \%$ had received no previous MMR dose. This situation was more frequent in clustered cases $(71.9 \%)$ than in non-clustered cases $(61.1 \%)$. These differences were larger in the age group of 2-14 year-olds $(76.0 \%$ in clustered versus $54.0 \%$ in nonclustered cases).

A total of 393 cases (19.2\%) were hospitalised. Although the majority of hospitalised cases were older than 15 years $(74.8 \%$ of total hospitalised cases), hospitalisation rates were highest, more than 50 per 100,000 population, in children under the age of two years in Andalusia. The severity of the disease, calculated as hospital admissions per cases was also high in children under the age of two-years (215 admissions per 1,000 cases) and adults over the age of 29 years (262 per 1,000. The most frequent complication in hospitalised patients was pneumonia (31.0\%), followed by digestive disorders (22.2\%), respiratory insufficiency and dyspnoea (14.3\%) and liver disorders (9.5\%). No encephalitides or deaths were reported.

Among the cases in this outbreak were 41 healthcare professionals, all between 25 and 39 years of age. None of them were fully vaccinated. There have been no reported cases of transmission from healthcare workers to hospital inpatients in this outbreak.

\section{Control measures}

At the beginning of the outbreak, control measures were implemented in all schools, kindergartens and health centres in affected areas and in work centres with a reported case, in accordance with the Plan for Elimination of Measles in Spain [3] and the Protocol of Alerts from the Ministry of Health of Andalusia [17].

Vaccination status was reviewed for all children attending schools in towns or districts in cities with one or more cases of measles. A dose of MMR vaccine was offered to all children and adolescents who were not fully vaccinated.

Cases were excluded from school until at least four days after rash onset. Measles susceptibility was determined for all children attending nursery schools in affected areas and for staff under the age of 40 years with no history of the disease or documented evidence of vaccination, offering susceptible individuals a dose of MMR vaccine. Vaccination status was determined by age. Children under 15 months were considered susceptible for not having reached the age of vaccination. Those over 40 years were not considered due to the high proportion of acquired immunity. 
Distribution of measles cases by age group: clustered with incidence rate $\geq 100$ per 100,000 versus non-clustered or clustered with incidence rate $<100$ per 100,000, Andalusia, January to August $2011(\mathrm{n}=1,759)$

\begin{tabular}{|c|c|c|c|c|c|c|c|}
\hline \multirow[t]{2}{*}{ Age group } & \multicolumn{3}{|c|}{ Clustered with incidence rate $\geq 100$ per 100,000} & \multicolumn{3}{|c|}{$\begin{array}{l}\text { Non-clustered or clustered with incidence rate } \\
\qquad 100 \text { per } 100,000\end{array}$} & \multirow[t]{2}{*}{$p$ value } \\
\hline & $\mathrm{N}$ & $\%$ & Cumulative $\%$ & $\mathrm{~N}$ & $\%$ & Cumulative $\%$ & \\
\hline o-14 months & 136 & 16,5 & 16,5 & 147 & 15,8 & 15,8 & 0,70 \\
\hline 15 months -4 years & 115 & 13,9 & 30,3 & 120 & 12,9 & 28,6 & 0,53 \\
\hline 5-14 years & 192 & 23,2 & 53,5 & 114 & 12,2 & 40,9 & $<0.0001$ \\
\hline $15-29$ years & 287 & 34,7 & 88,2 & 294 & 31,5 & 72,4 & 0,16 \\
\hline$\geq 30$ years & 97 & 11,7 & 100,0 & 257 & 27,6 & 100,0 & $<0.0001$ \\
\hline Total & 827 & 100,0 & - & 932 & 100,0 & - & - \\
\hline
\end{tabular}

The age groups in this Table differ from those in the Figures to accommodate for the fact that children under the age of 15 months are not eligible for vaccination.

At the beginning of the outbreak, unvaccinated children attending these nursery schools aged between 12 and 15 months received a dose of MMR vaccine. In the context of the current outbreak, also those aged between 6 and 11 months received a dose of MMR vaccine and were summoned for a second dose at the age of 15 months according to the vaccination schedule.

Unvaccinated contacts of cases with no previous history of measles were immunised with the MMR vaccine within 72 hours after exposure, except for those who could not be vaccinated (children under the age of six months, pregnant women and immunocompromised persons), who were treated with human polyvalent immunoglobulin.

As a pre-exposure measure at population level, the age for administration of the first dose of MMR vaccine was lowered to include all children older than 11 months in municipalities which had one or more cases. A second dose of MMR vaccine will be administered to these children when they reach the age of three years, according to the current vaccination schedule.

A dose of MMR was also offered to all healthcare workers under 40 years at hospitals or ambulatory health centres in the outbreak area who had no history of measles infection or documented evidence of measles vaccination. They were asked to sign a waiver when they did not accept it.

In week 17 of the outbreak, the Andalusian Health authorities summoned the heads of all Health Districts in the region in order to implement a campaign for reviewing and updating the MMR vaccination coverage in children between 2 and 16 years of age, starting first in areas dominated by underserved populations.

\section{Discussion}

The measles outbreak began among a Roma population with low vaccine coverage and spread rapidly due to the high number of susceptible individuals and the high mobility of this population, which generated a high number of contacts. This facilitated the spread to surrounding communities with pockets of unvaccinated susceptible children in many municipalities in Andalusia. These areas with low vaccination coverage saw an accumulation of clustered case among unvaccinated children, while in the rest of the population, the outbreak spread more slowly, leading to significant geographical differences in the spread of the outbreak. Other municipalities only saw non-clustered cases or small numbers of cases, with a higher proportion of young adults who became ill.

This outbreak occurred in a context of a recent re-emergence of measles in Europe since 2008 [8-15], with some outbreaks affecting Roma populations [9-11]. Also in other parts of Spain, measles outbreaks have been reported, with the same genotype as the one in Andalusia in Madrid in 2010 [18] and a different genotype $B_{3}$ in Granada in October 2010 [7].

Among the causes that may in recent years have contributed to the formation of pockets of susceptible children were the limited use of preventive services in certain population groups and the paradox that followed the success of childhood immunisation programmes. The high vaccination coverage made the disease disappear during the past decade and led to a low perception of risk regarding the severity of measles or its health and social costs. This situation may also have contributed to a further relaxation of health services in developing risk management strategies for vaccination of vulnerable populations. We understand that cultural or religious beliefs questioning vaccination or vaccine safety had no relevance for the origin and development of the outbreak described here.

In recent outbreaks reported in Europe [8] the largest proportion of cases occurred in childen aged between 5 and 14 years. In successive epidemic waves in 
Switzerland and France $[13-15,19]$, this has also been the most affected age group, and vaccination coverage for one dose of MMR vaccine was below $90 \%$.

In our outbreak, the largest proportion of cases were adults aged 15 to 39 years. Although the vaccination coverage in Andalusia in general is appropriate to interrupt transmission of the disease in the population (over $95 \%$ during the last 12 years), a seroprevalence study conducted in 1996 in the population between 2 and 40 years of age showed that more than $5 \%$ of individuals in the cohort born between 1977 and 1986 (currently between 25 and 34 years-old) were susceptible $[, 20]$. Updating the vaccination of these age groups has so far not been considered feasible, so more cases may occur in this age group in the future.

In addition, we saw a high incidence rate and a considerable number of hospital admissions among children younger than 15 months, who were not vaccinated because of their age. In particular the proportion of cases among children 12 to 15 months of age $(5.3 \%$ of total) indicates a need to lower the age for the first dose of MMR in our childhood vaccination schedule.

The most frequent complications in hospitalised patients were pneumonia, digestive disorders, respiratory insufficiency and dyspnoea, which is in line with the complications described in scientific literature [21]. We would like to point out that liver disorder was detected in 12 cases, involving aminotransferase elevation (nine cases), hepatomegaly (two cases) and cholestasis (one case). Half of these cases were male, the age ranged from 24 to 39 years, and none of them had any underlying disease. Although this complication is infrequent, it has also been described in literature $[22,23]$.

It is important to emphasise the importance of preventing measles transmission in healthcare through staff. The risk of disease in non-immune healthcare workers is much higher than in the general population and vaccination in this group must be strengthened $[24,25]$. About $20 \%$ of the cases in this outbreak were hospitalised, figures lower than reported in France (33.3\%) $[14,15]$ and higher than in Switzerland (15\%) [13]. To prevent transmission in waiting rooms of health centres, emergency rooms and hospital wards, training sessions were organised for staff of health services in the outbreak area, and a written waiver was requested from staff declining the offered vaccine. However, 41 healthcare workers became ill, which constitutes a high risk of nosocomial transmission to non-immune or immunocompromised patients, as the essential respiratory isolation measures are not sufficient to prevent nosocomial transmission [25].

In our view, interventions to control the outbreak, particularly through early notification of cases to facilitate early post-exposure immunisation, vaccination in schools and preschools, and lowering the age for vaccination in affected education institutions have probably reduced the intensity and duration of the outbreak especially in children.

Acknowledgments

We would like to thank those who contributed with their work to the study and control of the outbreak with special reference to health professionals at hospitals and health centres, as well as public health professionals at Provincial Offices of the Regional Ministry of Health, Health Districts and Health Management Areas of Andalusia. 


\section{References}

1. Eliminating measles and rubella and preventing congenital rubella infection: WHO European Region Strategic Plan 2005 2010. Copenhagen: World Health Organization Regional Office for Europe. 2005. Available from: http://www.euro.who.int/ InformationSources/Publications/Catalogue/20051123

2. Resolution. Renewed commitment to elimination of measles and rubella and prevention of congenital rubella syndrome by 2010 and Sustained support for polio-free status in the WHO European Region. Regional Committee for Europe. Sixtieth session. Moscow, 13-16 September 2010. Copenhagen: World Health Organization Regional Office for Europe; 2010. Available from: http://www.euro.who.int/ data/assets/pdf file/0016/122236/RC60_eRes12.pdf

3. Plan de eliminacion del sarampión en España. [Measles Elimination Plan in Spain]. Madrid: National Centre of Epidemiology, Institute of Health Carlos III; 2000. Spanish. Available from: http://www.isciii.es/ISCIII/es/contenidos/ $\mathrm{fd}$-servicios-cientifico-tecnicos/fd-vigilancias-alertas/fdenfermedades/fd-enfermedades-prevenibles-vacunacion/ PLANSARAMPION.pdf

4. Plan de Acción para la Eliminación del Sarampión en Andalucía [Action plan for measles elimination in Andalusia]. Sevilla: Dirección General de Salud Pública y Participación, Consejería de Salud, Junta de Andalucía [Andalusian Regional Ministry of Health]; 2001. Spanish. Available from: http://www.hvn.es/ servicios asistenciales/microbiologia - servicio/ficheros/ plansarampion_andalucia.pdf

5. Calendario de Vacunación Infantil, 2012. [Childhood vaccination calendar 2012]. Sevilla: Consejería de Salud, Junta de Andalucía [Andalusian Regional Ministry of Health]. [Accessed 18 Oct 2012]. Spanish. Available from: http://www. juntadeandalucia.es/salud/ZHD/vacunas2012/

6. Nieto-Vera J, Masa-Calles J, Dávila J, Molina-Font J, Jiménez M, Gallardo-García V, et al. An outbreak of measles in Algeciras, Spain, 2008 - a preliminary report. Euro Surveill. 2008;13(20):pii=18872. Available from: http://www. eurosurveillance.org/ViewArticle.aspx?Articleld $=18872$

7. López Hernández B, Laguna Sorinas J, Marín Rodríguez I, Gallardo García V, Pérez Morilla E, Mayoral Cortés JM. Spotlight on measles 2010: An ongoing outbreak of measles in an unvaccinated population in Granada, Spain, October to November 2010. Euro Surveill. 2010;15(50): pii=19746. Available from: http://www.eurosurveillance.org/ViewArticle. aspx?Articleld $=19746$

8. Measles surveillance 2 nd quarterly report 2010. EUVAC.NET. [Accessed 13 Oct 2010]. Available from: http://www.euvac.net/ graphics/euvac/pdf/2010_second.pdf

9. Six C, Blanes de Canecaude J, Duponchel JL, Lafont E, Decoppet A, Travanut M, et al. Spotlight on measles 2010: Measles outbreak in the Provence-Alpes-Côte d'Azur region, France, January to November 2010 - substantial underreporting of cases. Euro Surveill. 2010;15(50):pii=19754. Available from: http://www.eurosurveillance.org/ViewArticle. aspx?Articleld $=19754$

10. Stanescu A, Muscat M, Romaniuc A, Pipirigeanu R, Lupulescu E, Necula G, et al. Lazar M, Molnar G, Pistol A. Spotlight on measles 2010: An ongoing measles outbreak in the district of Neamt, Romania, August -September 2010. Euro Surveill. 2010;15(40): pii=19682. Available from: http://www. eurosurveillance.org/ViewArticle.aspx?Articleld=19682

11. Pervanidou D, Horefti E, Patrinos S, Lytras T, Triantafillou E, Mentis A, et al. Bonovas S, Panagiotopoulos T. Spotlight on measles 2010: Ongoing measles outbreak in Greece, January-July 2010. Euro Surveill. 2010;15(30):pii=19629. Available from: http://www.eurosurveillance.org/ViewArticle. aspx?Articleld $=19629$

12. Bätzing-Feigenbaum J, Pruckner U, Beyer A, Sinn G, Dinter A, Mankertz A, et al. Spotlight on measles 2010: Preliminary report of an ongoing measles outbreak in a subpopulation with low vaccination coverage in Berlin, Germany, JanuaryMarch 2010. Euro Surveill. 2010;15(13):pii=19527. Available from: http://www.eurosurveillance.org/ViewArticle. aspx?Articleld $=19527$

13. Richard JL, Masserey Spicher V. Large measles epidemic in Switzerland from 2006 to 2009: consequences for the elimination of measles in Europe. Euro Surveill. 2009;14(50):pii=19443. Available from: http://www. eurosurveillance.org/ViewArticle.aspx?Articleld=19443

14. C Baudon, I Parent du Châtelet, D Antona, F Freymuth, I Poujol, C Maine, et al. Caractéristiques de l'épidémie de rougeole démarrée en France depuis 2008: bilan des déclarations obligatoires pour les cas survenus jusqu'au 30 avril 2011. [Characteristics of the ongoing measles outbreak since 2008 in France: Review of mandatory reported for cases occurred before 30 April 2011]. Bulletin épidémiologique hebdomadaire. 20 Sep 2011;no 33-34. Available from: http://www.invs. sante.fr/content/download/18602/117933/version/5/file/ BEH_33_34_2011.pdf

15. Parent du Châtelet I, Antona D, Freymuth F, Muscat M, Halftermeyer-Zhou F, Maine C, et al. Spotlight on measles 2010: Update on the ongoing measles outbreak in France, 2008-2010. Euro Surveill. 2010;15(36):pii=19656. Available from: http://www.eurosurveillance.org/ViewArticle. aspx?Articleld $=19656$

16. European Commission. Commission Decision of 28 April 2008 (2008/426/EC) amending Decision 2002/253/EC laying down case definitions for reporting communicable diseases to the Community network under Decision No 2119/98/EC of the European Parliament and of the Council. Official Journal of the European Union 18.6.2008;L159/46. Available from: http://eurlex.europa.eu/LexUriServ/LexUriServ.do?uri=0J:L:2008:159:00 46:0090:EN:PDF

17. Protocolo de Alerta Epidemiológica por Sarampión. [Protocol of an epidemiological alert for measles]. Sevilla: Consejería de Salud, Junta de Andalucía [Andalusian Regional Ministry of Health]; 1 Aug 2008. Spanish. Available from: http://www. juntadeandalucia.es/salud/export/sites/csalud/galerias/ documentos/p_4_p_1_vigilancia_de_la_salud/Protocolos_ actuacion/sarampion.pdf

18. Informe anual del Plan de Eliminación del sarampión, Rubéola y Síndrome de Rubéola Congénita en España, 2010. [Annual report on the plan for the elimination of measles, rubella and congenital rubella syndrome in Spain, 2010]. Madrid: National Centre of Epidemiology, Institute of Health Carlos III; Aug 2011. Spanish. Available from: http://www.isciii.es/ISCIII/es/contenidos/fd-servicioscientifico-tecnicos/fd-vigilancias-alertas/fd-enfermedades/ $\mathrm{fd}$-enfermedades-prevenibles-vacunacion/Informe-Anual-PlanEliminacion-del-Sarampion-Rubeola-y-Sindrome-de-RubeolaCongenita-Espana-2010.pdf

19. Lang P, Piller U, Steffen R. Swiss national vaccination coverage survey: Vaccination coverage of children in Switzerland, 19992003. Zürich: University of Zurich, Institute for Social and Preventive Medicine; 2005.

20. 20.Gallardo García V, Camino Durán F, García León J, Escalera Urkiaha MA, Sánchez Cruz JJ, Cabrera León A, et al. Encuesta seroepidemiológica de Andalucía. [Seroepidemiological survey of Andalusia]. Sevilla: Ministry of Health, Junta de Andalucía; 1999. ISBN 84-89704-48-1. Spanish.

21. Perry RT, Halsey NA. The clinical significance of measles: a review. J Infect Dis. 2004;189 Suppl 1:S4-16.

22. Khatib R, Siddique M, Abbass M. Measles associated hepatobiliary disease: an overview. Infection. 1993;21(2):112-4

23. Satoh A, Kobayashi H, Yoshida T, Tanaka A, Kawajiri T, Oki Y, et al. Clinicopathological study on liver dysfunction in measles. Intern Med. 1999;38(5):454-7.

24. Botelho-Nevers E, Cassir N, Minodier P, Laporte R, Gautret $\mathrm{P}$, Badiaga S, et al.. Measles among healthcare workers: a potential for nosocomial outbreaks. Euro Surveill. 2011;16(2): pii=19764. Available from: http://www. eurosurveillance.org/ViewArticle.aspx?Articleld=19764

25. Williams WW, Preblud SR, Reichelderfer PS, Hadler SC. Vaccines of importance in the hospital setting. Problems and developments. Infect Dis Clin North Am. 1989;3(4):701-22. 